\title{
Turmeric powder in the diet of Japanese quails improves the quality of stored eggs
}

Açafrão em pó em dietas de codornas japonesas melhora a qualidade de ovos armazenados

${ }^{1}$ GUIMARÃES, Rívia Ribeiro

https://orcid.org/0000-0001-7990-0041

${ }^{1}$ OLIVEIRA, Maria Aparecida de https://orcid.org/0000-0002-7416-8477

${ }^{1}$ OLIVEIRA, Higor Castro

https://orcid.org/0000-0001-8264-0930
${ }^{1}$ DORÓ, Sarah Carvalho Oliveira Lima https://orcid.org/0000-0003-0638-7050

${ }^{1}$ MACHADO, Leonardo Azevedo https://orcid.org/0000-0002-1193-2239

${ }^{*}$ OLIVEIRA, Maria Cristina de https://orcid.org/0000-0002-3024-2276

${ }^{1}$ Universidade de Rio Verde, Faculdade de Medicina Veterinária, 75.901-910, Rio Verde/GO, Brasil

*Mail for correspondence: mcorv@yahoo.com.br

\section{SUMMARY}

This study evaluated the effect of turmeric powder (TP) on the productivity and egg quality of quails and on the quality of eggs stored at different temperatures for 7 or $14 \mathrm{~d}$. Quails were distributed in three treatments that consisted of sorghum-based diets with $1.5 \%$ and $3 \% \mathrm{TP}$ or zero TP inclusion, with five replicates for $84 \mathrm{~d}$. Eggs were stored at ambient temperature or refrigerated for 7 or $14 \mathrm{~d}$ in a $3 \times 2 \times 2$ factorial arrangement with three TP levels $\times$ two storage temperatures $(\mathrm{ST}) \times$ two storage periods $(\mathrm{SP})$. Inclusion of TP did not affect the performance of the quails or egg quality at $84 \mathrm{~d}$. Interaction SP $\times$ ST influenced the height and diameter of yolk and albumen, and the Haugh unit value. Eggs of quails with a diet supplemented with $3 \% \mathrm{TP}$ and stored for $14 \mathrm{~d}$ showed specific gravity similar to the eggs stored for $7 \mathrm{~d}$, despite the TP supplementation. It was concluded that diets with 3\% TP did not affect the performance and quality of fresh eggs but improved the quality of eggs stored for $14 \mathrm{~d}$ at ambient temperature.

Keywords: alimentary additive, egg quality, quail nutrition

\section{RESUMO}

Este estudo avaliou o efeito de açafrão em pó (AP) sobre a produtividade e qualidade de ovos de codornas e sobre a qualidade de ovos armazenados em diferentes temperaturas por 7 ou 14 dias. Codornas foram distribuídas em três tratamentos que consistiram em dietas baseadas em sorgo com (1,5 e 3\%) ou sem inclusão de AP e cinco repetições por 84 dias. Ovos foram armazenados em temperatura ambiente ou refrigerados por 7 ou 14 dias em arranjo fatorial $3 \times 2 \times 2$ com três níveis de AP $\times$ duas temperaturas de armazenamento (TA) $\times$ dois períodos de armazenamento (PA). A inclusão de AP não afetou o desempenho das codornas ou a qualidade de ovo aos 84 dias. A interação TA $\times$ 
PA influenciou a altura e o diâmetro de gema e albúmen e o valor de unidade Haugh. Ovos de codornas com dietas suplementadas com 3\% AP e armazenados por 14 dias mostraram peso específico similar ao de ovos armazenados por 7 dias, independente da suplementação com AP. Concluiu-se que dietas com 3\% de AP não afetaram o desempenho e qualidade de ovos frescos mas melhorou a qualidade de ovos armazenados por 14 dias em temperatura ambiente.

Palavras-chave: aditivo alimentar, qualidade de ovo, nutrição de codornas

\section{INTRODUCTION}

Corn is the main energetic ingredient used in animal diets. Several feeds may sometimes be used as a corn substitute to reduce the production costs. Sorghum is the most commonly used feed in these situations. However, sorghum has very low $\beta$-carotene (CHE et al., 2016) and when used in the diet of laying hens, a pigment must be added to the diet to avoid light yolks.

Yolk color is one of the main factors that influences the buying decision of consumers because it is associated with the nutritional value of the egg (MOURA et al., 2010). Another consumer demand is the consumption of healthy food with no synthetic additives (ATTIA et al., 2018). Hence, turmeric powder may be used as a natural pigment.

Turmeric rhizomes (Curcuma longa) are widely used as condiments and pigments in food. Curcumin is the main pigment in the turmeric rhizome (ATTIA et al., 2017). According to Bartov \& Bornstein (1966), birds do not synthesize pigments, but $20 \%-60 \%$ of the ingested pigment is deposited in the yolk.

Egg quality reflects the physical and chemical status of the eggs. Nutrition affects egg characteristics such as egg weight, egg yolk, and egg white proportion (RÉHAULT-GODBERT et al., 2019). Turmeric is a food that may improve egg quality by increasing the functions of the liver, where nutrient metabolism occurs and vitellogenin is produced, and reproductive organs, such as the magnum and uterus, where the albumen and the eggshell are produced, respectively (SARASWATI et al., 2013a).

Curcuminoids found in turmeric rhizomes $(2.5 \%-6.0 \%)$ consisted of curcumin (curcumin I), demethoxycurcumin (curcumin II), bisdemethoxycurcumin (curcumin III), and a cyclocurcumin. In commercial turmeric, curcumin I represents $70 \%$, curcumin II, $17 \%$, and curcumin III, 3\% (LEE et al., 2013).

Turmeric contains antioxidant (SUN et al., 2019), anti-inflammatory (HEWLINGS \& KALMAN, 2017), antiviral (ALAGAWANY et al., 2015), antitumor, and antimicrobial (MOSELHY et al., 2018) substances that improve body function (SARASWATI et al., 2013a), and consequently, productive performance, as shown by Attia et al. (2017), Nuraini \& Djulardi (2019), Kennedy et al. (2020), and Liu et al. (2020).

Most of the studies have focused only on the quality of fresh eggs; thus, this study was carried out to evaluate the effect of dietary supplementation with turmeric powder on the productivity and egg quality of Japanese quails as well as on the quality of eggs stored at ambient temperature or under refrigeration for 7 or $14 \mathrm{~d}$.

MATERIAL AND METHODS 
This study was approved by the Ethics Committee on Animal Use of the Universidade de Rio Verde (protocol $\mathrm{n}$. 01/14, approved on March 18, 2014).

In total, 105 Japanese quails, $50 \mathrm{~d}$ old, were distributed in a completely randomized design to three treatments and five replicates. The experimental period lasted $84 \mathrm{~d}$. Treatments consisted of sorghum-based diets containing turmeric powder $(0 \%, 1.5 \%$, and $3 \%)$. The evaluated levels were chosen according to preliminary studies published in the literature to elucidate contradictory results. Turmeric powder (TP) was obtained after washing, slicing, drying, and grinding of the rhizomes. Experimental diets were formulated according to the nutritional requirements for quails as recommended by Rostagno et al. (2011) (Table 1). Water and diets were provided ad libitum throughout the experiment.

Birds were housed in galvanized wire cages $(25 \mathrm{~L} \times 15 \mathrm{H} \times 33 \mathrm{~W}, \mathrm{~cm})$ equipped with gutter-type feeders and drinkers. The temperatures in the production facilities, from August to November, were $18{ }^{\circ} \mathrm{C}(\mathrm{min})$ and $31{ }^{\circ} \mathrm{C}$ (max). The light program was initiated when the birds were $40 \mathrm{~d}$ old with an initial supply of $14 \mathrm{~h}$ of light/day and increased per week of $30 \mathrm{~min}$ until it reached $17 \mathrm{~h}$ of light/day, which was retained until the end of the experimental period.

Table 1. Nutritional composition of the experimental diets

\begin{tabular}{lccc}
\hline & \multicolumn{3}{c}{ Turmeric powder (\%) } \\
\cline { 2 - 4 } Ingredients (kg) & $\mathbf{0 . 0}$ & $\mathbf{1 . 0}$ & $\mathbf{3 . 0}$ \\
\hline Soybean meal & 32.50 & 32.50 & 32.50 \\
Soybean oil & 6.84 & 6.84 & 6.84 \\
Ground sorghum & 50.00 & 50.00 & 50.00 \\
Turmeric powder & 0.00 & 1.00 & 3.00 \\
Dicalcium phosphate & 1.32 & 1.32 & 1.32 \\
Limestone & 5.41 & 5.41 & 5.41 \\
DL-Methionine 99\% & 0.09 & 0.09 & 0.09 \\
Commom salt & 0.33 & 0.33 & 0.33 \\
Premix 1 & 0.50 & 0.50 & 0.50 \\
Caolim & 3.00 & 1.50 & 0.00 \\
Antioxidant & 0.01 & 0.01 & 0.01 \\
\hline Calculated composition ${ }^{2}$ & & & \\
Crude protein (\%) & 19.13 & 19.13 & 19.13 \\
Metabolizable energy (kcal/kg) & 2930 & 2930 & 2930 \\
Calcium (\%) & 2.50 & 2.50 & 2.50 \\
Available phosphorus (\%) & 0.35 & 0.35 & 0.35 \\
Sodium (\%) & 0.15 & 0.15 & 0.15 \\
Total lysine (\%) & 1.09 & 1.09 & 1.09 \\
Total methionine (\%) & 0.55 & 0.55 & 0.55 \\
\hline
\end{tabular}

${ }^{1}$ Each kg contain: vit. A 1800000 UI; vit. $D_{3} 500000$ UI; vit. E 2000 UI; vit. $K_{3} 360$ mg; vit. $B_{12} 2400$ mcg; niacin $5000 \mathrm{mg}$; pantothenic acid $2000 \mathrm{mg}$; folic acid $80 \mathrm{mg}$; thiamine $300 \mathrm{mg}$; choline $100 \mathrm{~g}$; riboflavin 1,000 mg; pyiridoxine 300 mg; biotin 8 mg; Cu 2000 mg; Fe 8000 mg; I 200 mg; Mn 15 g; Se 60 mg; Zn $10000 \mathrm{mg}$; methionine $20 \mathrm{~g}$; chloro hydroxyquinoline $6000 \mathrm{mg}$; antioxidant $500 \mathrm{mg}$.

${ }^{2}$ According to Rostagno et al. (2011). 
The evaluated parameters were productive performance (laying rate, egg mass, daily feed consumption, and feed conversion) and egg quality (weight, specific gravity, Haugh unit, and $\mathrm{pH}$ of the egg; weight, height, and diameter of the yolk and albumen and yolk color; and weight and thickness of the eggshell). The specific gravity of eggs was determined by immersing them in saline solutions of different densities (1.05$\left.1.10 \mathrm{~g} / \mathrm{cm}^{3}\right)$. The Haugh unit was calculated using the following formula: $\mathrm{HU}=100 \times \log \left(\mathrm{H}-1.7 \times \mathrm{W}^{0.37}+7.6\right)$, where $\mathrm{H}$ is albumen height ( $\mathrm{mm})$, and $\mathrm{W}$ is egg weight $(\mathrm{g})$. Albumen weight $(\mathrm{g})$ was calculated as the difference between the weight of the entire egg and the combined weight of the yolk and eggshell (g). Eggshell thickness was measured as reported by Attia et al. (2020).

During the last $3 \mathrm{~d}$, all the eggs produced in each cage were weighed, and three were used to determine the weight, height, and diameter of the yolk and albumen. Eggshells were weighed. The albumen weight was obtained by subtracting the weight of the yolk and eggshell from the egg weight. The height and diameter of the yolk and albumen were measured using a formal caliper. Based on the data, the percentage of each component was calculated, along with the Haugh unit following the formula: $\mathrm{UH}=100 \times \log \left(\mathrm{H}-1.7 \times \mathrm{W}^{0.37}+7.6\right)$, where $\mathrm{H}$ is the albumen height ( $\mathrm{mm})$, and $\mathrm{W}$ is the egg weight $(\mathrm{g})$.

The remaining eggs were used to determine the specific gravity by immersion of the eggs in containers of saline solution $(\mathrm{NaCl})$, whose densities ranged from 1.050 to 1.100 , with intervals of 0.005. Eggshells were washed and air-dried to obtain the weight and thickness that was measured at three different points (at both the poles and lateral region of the shell) with a digital caliper with a precision of $0.0 \mathrm{~mm}$.

On the $84^{\text {th }}$ day, birds continued to receive the experimental diets. In total, 72 eggs were collected on the $85^{\text {th }}$ day and were stored at ambient temperature $\left(30{ }^{\circ} \mathrm{C} \pm 2.1{ }^{\circ} \mathrm{C}\right)$ for $7 \mathrm{~d}(36 \mathrm{eggs})$ and 14 d (36 eggs). Further, 72 eggs were collected on the $86^{\text {th }}$ day and stored under refrigeration $\left(4{ }^{\circ} \mathrm{C} \pm 0.6{ }^{\circ} \mathrm{C}\right)$ for 7 $\mathrm{d}$ (36 eggs) and $14 \mathrm{~d}$ (36 eggs). The experimental design was completely randomized in a $3 \times 2 \times 2$ factorial arrangement, with three TP levels $(0 \%$, $1.5 \%$, and $3 \%$ ) in the diets, two storage temperatures (Tp), and two storage periods (SP), with four replicates as the experimental unit with three eggs each, totaling 12 eggs per treatment. The same egg quality parameters were evaluated.

The results of the productive performance and egg quality obtained with the sorghum-based diets, with or without TP, were analyzed by ANOVA using the software SISVAR $^{\circledR}$ (FERREIRA, 2011). Results of the quality of the stored eggs were also analyzed by ANOVA, and when necessary, Tukey's test was used to compare the means at $5 \%$ probability.

\section{RESULTS AND DISCUSSION}

Inclusion of TP did not affect $(\mathrm{P}>0.05)$ the productive performance of the quails (Table 2). Inclusion of TP did not alter the productive performance, which means that it did not alter the diet palatability and nutrient use, and consequently, did not change the feed conversion, laying rate, or egg mass. Feed intake may be affected by feed palatability and glucose levels in the blood. Curcumin has an effect similar to insulin in the blood glucose control (ALSAUD, 2020; HARTOGH et al., 2020) and stimulates bile secretion (WANG et 
al., 2016), which is important for digestion. However, in studies with quails using TP doses of $0.5-2.0 \%$ (SILVA et al., 2018) or $0.1 \%, 0.2 \%$, and $0.3 \%$ (LAGANÁ et al., 2019), no change was observed in the feed intake and nutrient use. Working with laying hens, Laganá et al. (2011) evaluated a 2\% turmeric inclusion in the diet but did not note its effects on the productive performance of the birds. Similarly, Malekizadeh et al. (2012) studied the inclusion of $1 \%$ and $3 \%$ turmeric in the diet and did not report differences in egg production or egg mass.

Table 2. Performance of Japanese quails fed diets containing different levels of turmeric powder

\begin{tabular}{lccccc} 
& \multicolumn{3}{c}{ Turmeric powder $(\%)$} & & \\
\cline { 2 - 4 } Parameters & 0.0 & 1.5 & 3.0 & SEM & p value \\
\hline Feed intake $(\mathrm{g} / \mathrm{bird} / \mathrm{d})$ & 35.2 & 38.0 & 39.5 & 1.84 & 0.281 \\
Feed conversion $(\mathrm{kg} / \mathrm{kg})$ & 3.16 & 3.26 & 3.23 & 0.18 & 0.911 \\
Feed conversion $(\mathrm{kg} /$ dozen $)$ & 0.450 & 0.460 & 0.474 & 0.03 & 0.805 \\
Laying rate $(\%)$ & 94.3 & 97.7 & 98.3 & 1.71 & 0.247 \\
Egg mass $(\mathrm{g} / \mathrm{bird} /$ day $)$ & 11.2 & 11.7 & 12.2 & 0.32 & 0.154 \\
\hline
\end{tabular}

$\mathrm{SEM}=$ standard error of the mean.

Egg quality was not affected $(\mathrm{P}>0.05)$ by treatment at the $84^{\text {th }}$ day of rearing (Table 3). Turmeric levels in the diet did not influence egg quality and did not change the yolk color, which agrees with the results of Gumus et al. (2018), Laganá et al. (2019), and Liu et al. (2020) using laying hens. Our results disagree with the reports of Silva et al. (2018), who noted a significant change in the yolk color using $0.5-2.0 \%$ turmeric powder in the diet of Japanese quails. Nuraini and Djulardi (2019) noted a significant change in the yolk color using 5 to 20 ppm turmeric powder in the diet of Japanese quails; the values varied from 8.32 (control) to 10.55 (20 ppm) as per the colorimetric fan. Klassing (1998) elucidated that pigment deposition in tissues depends on the amount present in the diet and the ability of the bird to digest, absorb, and metabolize the pigment. 
Table 3. Quality of eggs from Japanese quails fed with diets containing different levels of turmeric powder

\begin{tabular}{|c|c|c|c|c|c|}
\hline \multirow[b]{2}{*}{ Parameters } & \multicolumn{3}{|c|}{ Turmeric powder (\%) } & \multirow[b]{2}{*}{ SEM } & \multirow[b]{2}{*}{$\mathrm{p}$ value } \\
\hline & 0.0 & 1.5 & 3.0 & & \\
\hline \multicolumn{6}{|l|}{ Egg } \\
\hline Weight $(g)$ & 11.5 & 11.3 & 11.6 & 0.13 & 0.198 \\
\hline Specific gravity $\left(\mathrm{g} / \mathrm{cm}^{3}\right)$ & 1.071 & 1.074 & 1.072 & 0.001 & 0.265 \\
\hline $\mathrm{pH}$ & 7.81 & 7.73 & 7.80 & 0.31 & 0.979 \\
\hline \multicolumn{6}{|l|}{ Yolk } \\
\hline Weight (g) & 3.69 & 3.70 & 3.83 & 0.14 & 0.721 \\
\hline Height (mm) & 12.6 & 12.3 & 12.7 & 0.32 & 0.670 \\
\hline Diameter (mm) & 24.7 & 24.3 & 24.8 & 0.57 & 0.812 \\
\hline Color & 1.90 & 1.60 & 1.80 & 0.21 & 0.608 \\
\hline \multicolumn{6}{|l|}{ Albumen } \\
\hline Weight (g) & 7.03 & 6.56 & 6.75 & 0.22 & 0.338 \\
\hline Height (mm) & 5.20 & 5.10 & 5.10 & 0.28 & 0.958 \\
\hline Diameter (mm) & 44.6 & 49.0 & 48.3 & 1.52 & 0.132 \\
\hline Haugh unit & 93.4 & 93.1 & 92.7 & 1.41 & 0.964 \\
\hline \multicolumn{6}{|l|}{ Shell } \\
\hline Weight (g) & 0.825 & 1.027 & 1.050 & 0.11 & 0.298 \\
\hline Thickness (mm) & 0.212 & 0.206 & 0.224 & 0.006 & 0.142 \\
\hline
\end{tabular}

$\mathrm{SEM}=$ standard error of the mean.

Regarding eggshell quality, curcumin could improve the uterine microenvironment and thus, increase calcium deposition and consequently, the weight and thickness of the eggshell (Radwan et al. 2008). However, this effect was not observed in our study.

Saraswati et al. (2013b) reported no effect of TP on egg and eggshell weight, but eggs had a thinner eggshell and a higher diameter and height of yolk and albumen, with a higher Haugh unit value. Later, Saraswati et al. (2016) evaluated turmeric at doses of 0,54 , and 108 $\mathrm{mg} / \mathrm{bird} /$ day and did not verify the effect on the egg weight, weight, thickness of the eggshell, height and diameter of the yolk and albumen, and Haugh unit.

There was no effect $(\mathrm{P}>0.05)$ of TP $x$ storage temperature $\times$ storage period on egg quality. However, albumen weight was lower $(\mathrm{P}<0.05)$ in eggs stored at ambient temperature and increasing the storage period from $7 \mathrm{~d}$ to $14 \mathrm{~d}$ resulted in lower $(\mathrm{P}<0.05)$ weight of the egg and albumen (Table 4).

The decline in the quality of stored eggs occurred because of the degradation of the egg protein, ovalbumin. This degradation results in water formation, which migrates to the yolk, increases its weight, and causes dissociation of carbonic acid, one of the buffer system components in albumen, which dissociates in water and $\mathrm{CO}_{2}$ (FEDDERN et al., 2017). Refrigeration delays these reactions, and at ambient temperature, the albumen loses water more easily to the environment and to the yolk, which contributed to the $0.3 \mathrm{~g}$ reduction in weight. Al-Sagan et al. (2020) demonstrated that $\mathrm{pH}$ is related to water-holding capacity in broiler meat. Independent of the storage temperature, increasing the storage period negatively influenced albumen weight, and consequently, the egg weight was reduced by $0.43 \mathrm{~g}$. 
Similar results were found by storage period (5 and $15 \mathrm{~d}$ ); Figueiredo Nepomuceno et al. (2014), who also did et al. (2011) used eggs of hens stored at not note the changes in the weight, percentage of yolk, and eggshell thickness of the eggs of quails due to the ambient temperature and refrigerated and noted changes in the weight and percentage of egg components. 
Rev. Bras. Saúde Prod. Anim., Salvador, v.22, 01 - 18, e2122052021, 2021 http://dx.doi.org/10.1590/S1519-99402122052021

Table 4. Quality of eggs from Japanese quails fed with diets containing different levels of turmeric powder and stored at different temperatures for different periods

\begin{tabular}{|c|c|c|c|c|c|c|}
\hline Parameters & $\begin{array}{c}\text { Egg } \\
\text { weight }(\mathrm{g})\end{array}$ & $\begin{array}{c}\text { Yolk } \\
\text { weight }(\mathrm{g})\end{array}$ & $\begin{array}{l}\text { Yolk } \\
\text { color }\end{array}$ & $\begin{array}{c}\text { Albumen } \\
\text { weight (g) }\end{array}$ & $\begin{array}{c}\text { Eggshell } \\
\text { weight }(\mathrm{g})\end{array}$ & $\begin{array}{c}\text { Eggshell } \\
\text { thickness }(\mathrm{mm})\end{array}$ \\
\hline & \multicolumn{6}{|c|}{ Effect of the levels of turmeric powder (\%) } \\
\hline 0.0 & 11.5 & 3.73 & 1.57 & 6.72 & 0.96 & 0.321 \\
\hline 1.5 & 11.1 & 3.72 & 1.65 & 6.39 & 0.99 & 0.273 \\
\hline \multirow[t]{2}{*}{3.0} & 11.4 & 3.65 & 1.70 & 6.73 & 0.98 & 0.218 \\
\hline & \multicolumn{6}{|c|}{ Effect of the storage temperature } \\
\hline Refrigeration & 11.4 & 3.70 & 1.64 & $6.76^{\mathrm{a}}$ & 0.98 & 0.324 \\
\hline \multirow[t]{2}{*}{ Ambient } & 11.2 & 3.69 & 1.65 & $6.46^{\mathrm{b}}$ & 0.97 & 0.217 \\
\hline & \multicolumn{6}{|c|}{ Effect of the storage period (days) } \\
\hline 7 & $11.5^{\mathrm{a}}$ & 3.76 & 1.77 & $6.76^{\mathrm{a}}$ & 0.98 & 0.316 \\
\hline 14 & $11.1^{\mathrm{b}}$ & 3.64 & 1.52 & $6.46^{\mathrm{b}}$ & 0.97 & 0.225 \\
\hline \multirow[t]{2}{*}{ SEM } & 0.31 & 0.09 & 0.14 & 0.11 & 0.02 & 0.05 \\
\hline & \multicolumn{6}{|c|}{$p$ values } \\
\hline Turmeric powder (TP) & 0.057 & 0.784 & 0.827 & 0.050 & 0.712 & 0.303 \\
\hline Storage temperature (ST) & 0.077 & 0.940 & 0.920 & 0.023 & 0.461 & 0.050 \\
\hline Storage period (SP) & 0.002 & 0.249 & 0.140 & 0.022 & 0.461 & 0.092 \\
\hline $\mathrm{TP} \times \mathrm{ST} \times \mathrm{SP}$ & 0.935 & 0.394 & 0.487 & 0.522 & 0.772 & 0.280 \\
\hline $\mathrm{TP} \times \mathrm{ST}$ & 0.630 & 0.496 & 0.516 & 0.329 & 0.369 & 0.375 \\
\hline $\mathrm{TP} \times \mathrm{SP}$ & 0.138 & 0.190 & 0.451 & 0.800 & 0.310 & 0.376 \\
\hline $\mathrm{ST} \times \mathrm{SP}$ & 0.203 & 0.986 & 0.619 & 0.116 & 0.316 & 0.064 \\
\hline
\end{tabular}

$\mathrm{SEM}=$ standard error of the mean.

Means followed by different letters in the columns, are different by Tukey test. 
With respect to yolk color of the eggs, the results concur with those of Laganá et al. (2012), who did not observe changes in the yolk color of eggs from hens fed a diet containing $2 \%$ curcumin and stored at ambient temperature for up to $28 \mathrm{~d}$, compared with the control treatment (with no curcumin).

The inclusion of 3\% turmeric powder in the diet caused an increase in albumen diameter (Table 5). Hens supplemented with curcumin at $200 \mathrm{mg} / \mathrm{kg}$ showed higher estrogen levels, according to Liu et al. (2020). Albumen is mainly synthesized in the tubular gland cells in the magnum and comprises ovalbumin, conalbumin, ovomucoid, and lysozyme. The synthesis of these molecules has been associated with the hormone estrogen (MISHRA et al., 2020).

The interaction of temperature $\times$ period of storage affected $(\mathrm{P}<0.05)$ the height and diameter of the yolk and albumen as well as the Haugh unit value of the eggs. Increasing the storage period from 7 to $14 \mathrm{~d}$, independent of the storage temperature, resulted in a reduction $(\mathrm{P}<$ 0.05 ) in yolk height, particularly when the eggs were stored at ambient temperature. Eggs stored at ambient temperatures exhibited yolk with lower diameter $(\mathrm{P}<0.05)$, albumen with a lower height, and consequently, lower Haugh unit values (Table 5).

Storing the eggs for 14 days, independent of the storage temperature, resulted in reduction of the yolk height, particularly when the eggs were stored at ambient temperatures, compared to eggs stored for 7 days. Eggs stored at ambient temperatures had lower yolk diameter, albumen height and, consequently, lower Haugh unit values. 
Table 5. Height and diameter of the yolk, albumen and Haugh unit value of eggs from Japanese quails fed with diets containing different levels of turmeric powder and stored at different temperatures for different periods

\begin{tabular}{|c|c|c|c|c|c|}
\hline \multirow[b]{2}{*}{ Parameters } & \multicolumn{2}{|c|}{ Yolk } & \multicolumn{2}{|c|}{ Albumen } & \multirow{2}{*}{$\begin{array}{c}\text { Haugh } \\
\text { unit }\end{array}$} \\
\hline & $\begin{array}{c}\text { Height } \\
(\mathrm{mm})\end{array}$ & $\begin{array}{l}\text { Diameter } \\
(\mathrm{mm})\end{array}$ & $\begin{array}{l}\text { Height } \\
(\mathrm{mm})\end{array}$ & $\begin{array}{c}\text { Diameter } \\
\text { (mm) }\end{array}$ & \\
\hline & & \multicolumn{4}{|c|}{ Effect of the levels of turmeric powder (\%) } \\
\hline 0.0 & 7.70 & 22.5 & 2.35 & $42.8^{b}$ & 75.5 \\
\hline 1.5 & 7.73 & 22.0 & 2.62 & $40.9^{\mathrm{b}}$ & 77.7 \\
\hline 3.0 & 7.85 & 22.0 & 2.75 & $44.0^{\mathrm{a}}$ & 78.4 \\
\hline & & \multicolumn{4}{|c|}{ Effect of the storage temperature } \\
\hline Refrigeration & 10.45 & 22.7 & 2.78 & 41.0 & 78.8 \\
\hline Ambient & 5.07 & 21.7 & 2.37 & 44.2 & 75.5 \\
\hline & & \multicolumn{4}{|c|}{ Effect of the storage period (days) } \\
\hline 7 & 8.28 & 22.0 & 3.37 & 41.4 & 82.9 \\
\hline 14 & 7.23 & 22.4 & 1.78 & 43.8 & 71.5 \\
\hline \multicolumn{6}{|c|}{ Effect of the interaction storage temperature $(\%) \times$ storage period } \\
\hline $\mathrm{R} \times 7$ & $10.67^{\mathrm{a}}$ & $22.4^{\mathrm{a}}$ & $3.20^{\mathrm{a}}$ & $42.0^{\mathrm{bc}}$ & $84.2^{\mathrm{a}}$ \\
\hline $\mathrm{R} \times 14$ & $6.00^{\mathrm{b}}$ & $22.9^{\mathrm{a}}$ & $3.53^{\mathrm{a}}$ & $39.7^{\mathrm{c}}$ & $81.5^{\mathrm{a}}$ \\
\hline $\mathrm{A} \times 7$ & $10.33^{\mathrm{a}}$ & $21.7^{\mathrm{b}}$ & $2.37^{\mathrm{b}}$ & $45.6^{\mathrm{a}}$ & $76.1^{\mathrm{b}}$ \\
\hline $\mathrm{A} \times 14$ & $4.14^{\mathrm{c}}$ & $21.8^{\mathrm{b}}$ & $1.20^{\mathrm{c}}$ & $42.8^{b}$ & $66.8^{c}$ \\
\hline SEM & 0.19 & 0.26 & $\begin{array}{l}0.12 \\
p \text { val }\end{array}$ & 0.82 & \\
\hline Turmeric powder (TP) & 0.845 & 0.301 & 0.082 & 0.039 & 0.081 \\
\hline Storage temperature (ST) & 0.001 & 0.002 & 0.006 & 0.002 & 0.004 \\
\hline Storage period (SP) & 0.001 & 0.309 & 0.001 & 0.011 & 0.001 \\
\hline $\mathrm{TP} \times \mathrm{ST} \times \mathrm{SP}$ & 0.417 & 0.882 & 0.604 & 0.107 & 0.726 \\
\hline $\mathrm{TP} \times \mathrm{ST}$ & 0.369 & 0.963 & 0.392 & 0.726 & 0.465 \\
\hline $\mathrm{TP} \times \mathrm{SP}$ & 0.467 & 0.296 & 0.574 & 0.054 & 0.626 \\
\hline $\mathrm{ST} \times \mathrm{SP}$ & 0.001 & 0.485 & 0.001 & 0.716 & 0.001 \\
\hline
\end{tabular}

$\mathrm{SEM}=$ standard error of the mean.

Means followed by different letters in the columns, are different by Tukey test.

Further, as the egg ages, the yolk absorbs water from the albumen and becomes wider with a fragile vitelline membrane, which causes a reduction in its height. The water loss is influenced by the temperature and storage period. In eggs stored for $7 \mathrm{~d}$, independent of the temperature, the yolk height did not change; however, in eggs stored for $14 \mathrm{~d}$ under refrigeration, the yolk height was higher $(6.00 \mathrm{~mm})$ than in the eggs stored at ambient temperature $(4.14 \mathrm{~mm})$.
The reduction in the Haugh unit value occurred due to the dissociation of the carbonic acid-producing water and $\mathrm{CO}_{2}$. The $\mathrm{CO}_{2}$ is lost to the environment, and the $\mathrm{pH}$ of the egg becomes more alkaline. Mucin fibers provide the gel structure to the egg. In an alkaline environment, the fibers become more resistant and the albumen becomes more watery, decreasing its height and increasing its diameter, which will reduce the Haugh unit value (EKE et al., 2013). 
According to Rocha et al. (2013), the ovalbumin also undergoes hydrolysis with a destruction of its protein structure, weakening of its vitelline membrane and liquefaction, loss of viscosity, and subsequent reduction of the albumen height. Similar results were found by Park et al. (2012), who did not verify an effect of turmeric on the eggs but increased the storage period from 7 to 14 $\mathrm{d}$, resulted in hens' eggs with a lower Haugh unit value and by Lee et al. (2016), who studied laying hens' eggs stored for $30 \mathrm{~d}$.

Turmeric supplementation increased albumen diameter without decreasing its height. It is possible that active substances in the turmeric stimulate the growth of epithelial cells and tubular glands in the magnum, responsible for synthesizing and secreting albumen (SARASWATI et al. 2013b).

The interaction of turmeric powder supplementation $\times$ storage period was significant $(\mathrm{P}<0.05)$ for eggs from quails with diets supplemented with $3 \%$ turmeric powder and stored for $14 \mathrm{~d}$, showing specific gravity similar to the eggs stored for $7 \mathrm{~d}$, independent of the turmeric supplementation (Table 6). Specific gravity may be positively correlated to the resistance of the eggshell and negatively correlated with the air chamber size (ABDALLAH et al., 1993). The reduction in specific gravity occurs due to water loss from the egg, which leads to a progressive increase in the air chamber (SANTOS et al., 2009). This loss is higher in eggs stored at ambient temperatures or for long time periods. 
Table 6. Specific gravity of the entire eggs from Japanese quails fed with diets containing different levels of turmeric powder and stored at different temperature for different periods

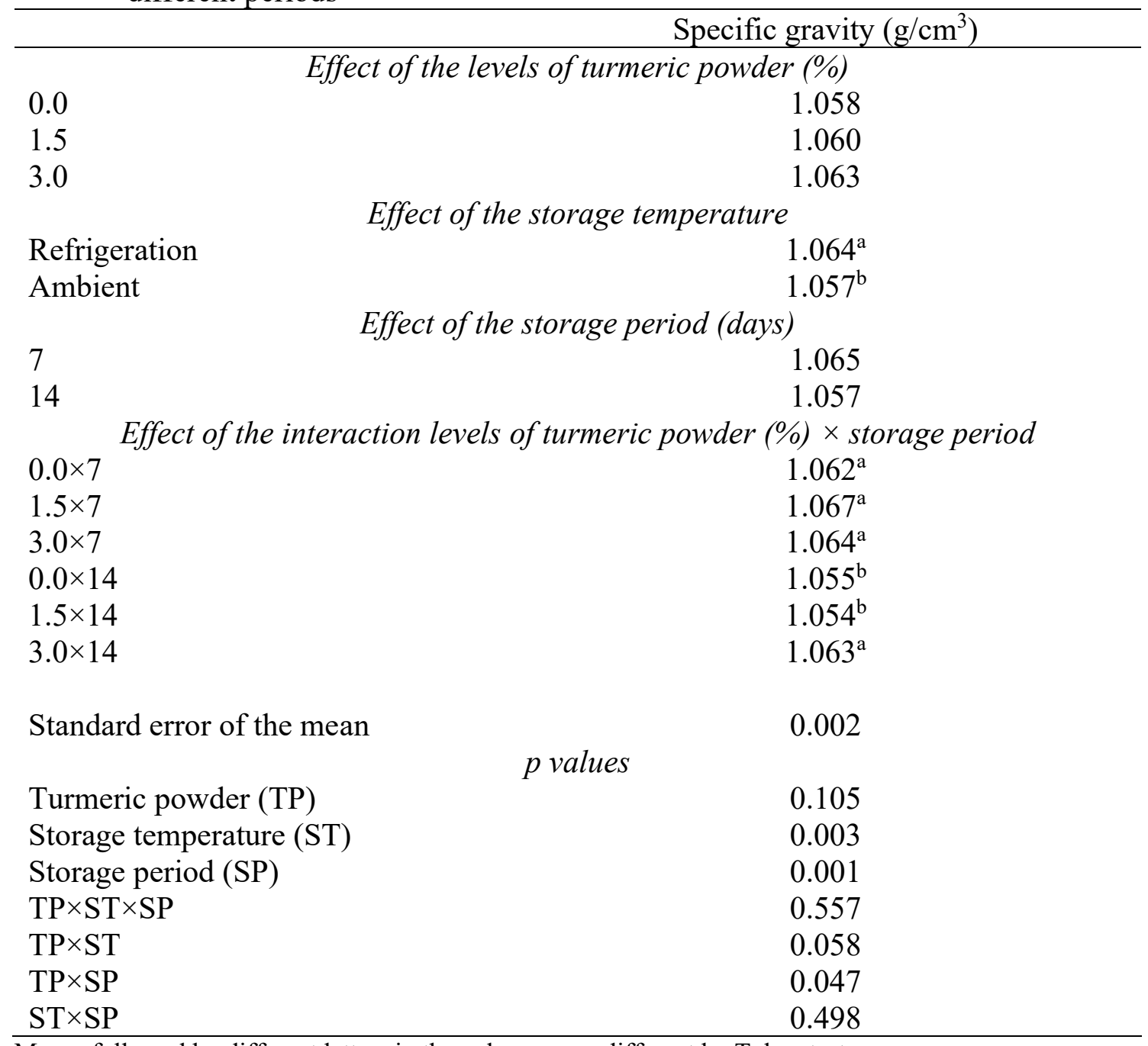

Means followed by different letters in the columns, are different by Tukey test.

As mentioned before, curcumin could improve the uterine microenvironment where the eggshell is formed and increase calcium deposition and the eggshell weight. No effect was observed on the shell, but it is possible that a higher calcium deposition occurred in eggs obtained from the birds fed with diets containing 3\% turmeric powder and stored for $14 \mathrm{~d}$. Curcumin is a weak acid with three labile protons (LEE et al., 2013; PRIYADARSINI, 2014), and intestinal acidification, even mild, results in higher solubilization and absorption of minerals, including calcium. In addition, turmeric also contains flavonoids that act like estrogen, improving calcium deposition in the eggshell (RAHARDJA et al., 2015).

Laganá et al. (2012) evaluated the quality of eggs from hens fed with diets containing $2 \%$ curcumin and stored at ambient temperatures for up to $21 \mathrm{~d}$. The authors did not report effect of the pigment; however, there was a linear decline in the specific gravity due the increase in the storage period. 
Egg $\mathrm{pH}$ was influenced by the interaction between turmeric levels and storage temperature $(\mathrm{P}<0.05)$. Refrigerated eggs showed similar $\mathrm{pH}$ values, independent of dietary turmeric level. Eggs stored at ambient temperatures had a more alkaline $\mathrm{pH}(8.08)$ when they were from non-supplemented quails (Table 7).

During ovalbumin degradation, water and $\mathrm{CO}_{2}$ are formed. The $\mathrm{CO}_{2}$ is lost to the environment through the eggshell pores, which results in an increase (alkalinization) of the egg $\mathrm{pH}$ (FEDDERN et al., 2017). Refrigerated eggs had similar $\mathrm{pH}$ values, independent of dietary turmeric level. However, eggs from non-supplemented quails and stored at ambient temperature had $\mathrm{pH}$ values superior to those of the eggs from birds fed diets supplemented with $1.5 \%$ and 3\% turmeric, demonstrating the antioxidant effect of curcumin. Egg $\mathrm{pH}$ increases as storage time and storage temperature also increase (AYOOLA et al., 2016; LEE et al., 2016; HAGAN and EICHIE, 2019), and antioxidants may delay the degradation of ovalbumin and inhibit lipid peroxidation in the yolk and, thus, retain the $\mathrm{pH}$ and quality of the eggs for longer, as demonstrated by Attia et al. (2017) in broiler meat. 
Table 7. $\mathrm{pH}$ of the entire eggs from Japanese quails fed with diets containing different levels of turmeric powder and stored at different temperature for different periods

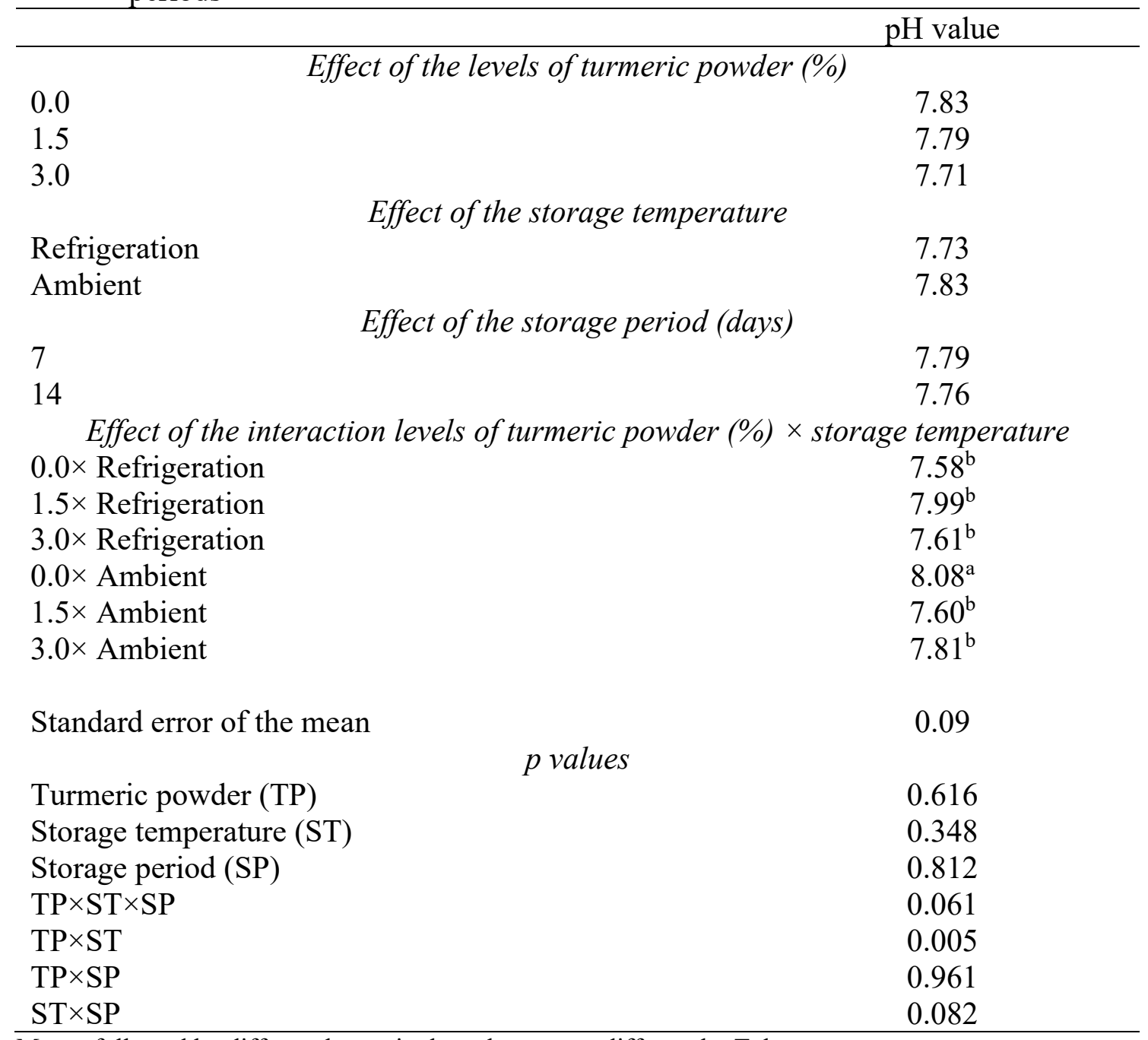

Means followed by different letters in the columns, are different by Tukey test.

\section{CONCLUSION}

It was concluded that a diet supplemented with $3 \%$ turmeric powder may be used for Japanese quails to improve albumen quality, specific gravity, and $\mathrm{pH}$ value of eggs stored for up to $14 \mathrm{~d}$ at ambient temperature.

\section{REFERENCES}

ABDALLAH, A.G.; HARMS, R.H.; EL-HUSSEINY, O. Various methods of measuring shell quality in relation to percentage of cracked egg. Poultry

Science, v. 72, n. 1, 2038-2043, 1993.

ALAGAWANY, M.M.; FARAG, M.A.; DHAMA, K. Nutritional and biological effects of turmeric (Curcuma longa) supplementation on performance, serum biochemical parameters and oxidative status of broiler chicks exposed to endosulfan in the diets. Asian Journal of Animal Veterinary Advance, v. 10, n. 2, 86-96, 2015. 
AL-SAGAN, A.A.; KHALIL, S.; HUSSEIN, E.O.S.; ATTIA, Y.A. Effects of fennel seed powder supplementation on growth performance, carcass characteristics, meat quality, and economic efficiency of broilers under thermoneutral and chronic heat stress conditions. Animals, v. $10,206,2020$.

AL-SAUD, N.B.S. Impact of curcumin treatment on diabetic albino rats. Saudi Journal of Biological Sciences, v. 27, n. 2, p. 689-694, 2020.

ATTIA, Y.A.; AL-HARTHI, M.A.; ELMAATY, H.M.A. Calcium and cholesterol levels in late-phase laying hens: effects on productive traits, egg quality, blood biochemistry, and immune responses. Frontiers

Veterinary Sciences, v. 7, 389, 2020.

ATTIA, Y.A.; AL-HARTHI, M.A.; HASSAN, S.S. Turmeric (Curcuma longa Linn.) as a phytogenic growth promoter alternative for antibiotic and comparable to mannan oligosaccharides for broiler chicks. Revista Mexicana de Ciencias Pecuárias, v. 8, n. 1, p. 11-21, 2017.

ATTIA, Y.A.; BAKHASHWAIN, A.A.; BERTU, N.K. Utilization of thyme powder (Thyme vulgaris L.) as a growth promoter alternative to antibiotics for broiler chickens raised in a hot climate. European Poultry Science, v. 82, 238, 2018.

AYOOLA, M.O.; ALABI, O.M.; ADEREMI, F.; OGUNTUNJI, A. Relationship of temperature and length of storage on $\mathrm{pH}$ of internal contents of chicken table egg in humid tropics.

Biotechnolgy in Animal Husbandry, v. 32, n. 3, p. 285-296, 2016.
BARTOV, I.; BORNSTEIN, S. Studies on egg yolk pigmentation: effect of ethoxiquim on xanthophylls within and among genetic sources. Poultry Science, v. 45, n. 2, 297-305, 1966.

CHE, P.; ZHAO, Z.Y.; GLASSMAN, K.; DOLDE, D.; HU, T.X.; JONES, T.J.; GRUIS, D.F.; OBUKOSIA, S.; WANBUGU, F.; ALBERTSEN, M.C. Elevated vitamin $\mathrm{E}$ content improves all-trans- $\beta$-carotene accumulation and stability in biofortified sorghum.

Proceedings of the National Academy of Sciences of the United State of America, v. 113, n. 39, p. 1104011045, 2016.

EKE, M.O.; OLAITAN, N.I.; OCHEFU, J.H. Effect of storage conditions on the quality attributes of shell (table) eggs. Official Journal of Nigerian Institut of Food Science and Technology, v. 31, n. 2, 18-24, 2013.

FEDDERN, V.; DE PRÁ, M.C.; MORES, R.; NICOLOSO, R.S.; COLDEBELLA, A.; ABREU, P.G. Egg quality assessment at diferente storage conditions, seasons and laying hen strains. Ciência e Agrotecnologia, v. 41, n. 3, p. 322-333, 2017.

FERREIRA, D.F. Sisvar: a computer statistical analysis system. Ciência e Agrotecnologia, v. 35, n. 6, p. 10391042, 2011.

FIGUEIREDO, T.C.; CANÇADO, S.V.; VIEGAS, R.P.; RÊGO, I.O.P.; LARA, L.J.C.; SOUZA, M.R.; BAIÃO, N.C. Qualidade de ovos comerciais submetidos a diferentes condições de armazenamento. Arquivo Brasileiro de Medicina Veterinária e Zootecnia, v. 63, n. 3, p. 712-720, 2011. 
GUMUS, H.; OGUZ, M.N.; BUGDAYCI, K.E.; OGUZ, F.K. Effects of sumac and turmeric as feed additives on performance, egg quality traits, and blood parameters of laying hens. Brazilian Journal of Animal Science, v. 47, e20170114, 2018.

HAGAN, J.K.; EICHIE, F.O. Egg quality of two layer strains as influenced by extended storage periods and storage temperatures. Livestock Research for Rural Development, v. 31, n. 9, article 145, 2019.

HARTOGH, D.J.D.; GABRIEL, A.; TSIANI, E. Antidiabetic properties of curcumin I: evidence from in vitro studies. Nutrients, v. 12, n. 1, p. 118, 2020.

HEWLINGS, S.J.; KALMAN, D.S. Curcumin: a review of its' effects on human health. Foods, v. 6, n. 10, 92, 2017.

KENNEDY, O.O.O.; MBABA, E.N.; ISO, I.E.; HALILU, A.; ROBERT, A.N.; MICHEAL, A.N.B. Effects of turmeric rhizome powder on growth, carcass and meat quality of Japanese quails fed sorghum-soybean-based diets. Livestock Science, v. 11, n. 1, p. 1-7, 2020.

KLASSING, K.C. Comparative avian nutrition. New York: CAB

International, 1998. 350p.

LAGANÁ, C.; PIZZOLANTE, C.C.; SALDANHA, E.S.P.B.; MORAES, J.E. Turmeric root and annatto seed in second-cycle layer diets: performance and egg quality. Brazilian Journal of Poultry Science, 13, n. 3, p. 171-176, 2011.
LAGANÁ, C.; PIZZOLANTE, C.C.; TURCO, P.H.N.; MORAES J.E.; SALDANHA, E.S.P.B. Influence of the natural dyes bixin and curcumin in the shelf live of eggs from laying hens in the second production cycle. Acta Scientiarum. Animal Science, v. 34, n. 2, p. 155-159, 2012.

LAGANÁ, C.; SALDANHA, E.S.P.; SARTORI, J.R.; GONZALES, E.; LUCIANO, R.L.; ZANATTA, G.; FASCINA, V.B. Turmeric and vitamin $\mathrm{E}$ on the performance and quality of eggs from white layers. Agricultural Sciences, v. 10, n. 6, p. 720-726, 2019.

LEE, M.H.; CHO, E.J.; CHOI, E.S.; SOHN, S.H. The effect of storage period and temperature on egg quality in commercial eggs. Korean Journal of Poultry Science, v. 43, n. 1, p. 31-38, 2016.

LEE, W.H.; LOO, C.Y.; BEBAWY, M.; LUK, F.; MASON, R.S.;

ROHANIZADEH, R. Curcumin and its derivatives: their application in neuropharmacology and neuroscience in the $21^{\text {st }}$ century. Current

Neuropharmacology, 11, n. 4, p. 338378, 2013.

LIU, M.; LU, Y.; GAO, P.; XIE, X.; LI, D.; YU, D.; YU, M. Effect of curcumin on laying performance, egg quality, endocrine hormones, and immune activity in heat-stressed hens. Poultry Science, v. 99, n. 4, p. 2196-2202, 2020.

MALEKIZADEH, M.; MOEINI, M.M.; GHAZI, Sh. The effects of different levels of ginger (Zingiber officinale Rosc) and turmeric (Curcuma longa Linn) rhizomes powder on some blood metabolites and production performance 
characteristics of laying hens. Journal of Agricultural Science and

Technology, 14, n. 1, p. 127-134, 2012. MISHRA, B.; SAH, N.; WASTI, S.

Genetic and hormonal regulation of egg formation in the oviduct of laying hens. In: KAMBOH, A.A. Poultry - an advanced learning. IntechOpen:

London, 2020. Available in

$<$ https://www.intechopen.com/books/po ultry-an-advanced-learning/genetic-andhormonal-regulation-of-egg-formationin-the-oviduct-of-laying-hens $>$.

Accessed at Ago 27, 2020.

MOSELHY, S.S.; RAZVI, S.; HASAN, N.; BALAMASH, K.S.; ABULNAJA, K.O.; YAGHMOOR, S.S.; YOUSSRI, M.A.; KUMOSANI, T.A.; AL-MALKI, A.L. Multifaceted role of a marvel golden molecule, curcumin: a review.

Indian Journal of Pharmaceutical Sciences, v. 80, n. 3, p. 400-411, 2018.

MOURA, A.M.A.; FONSECA, J.B.; RABELLO, C.B.V.; TAKATA, F.N.; OLIVEIRA, N.T.E. Desempenho e qualidade do ovo de codornas japonesas alimentadas com rações contendo sorgo. Revista Brasileira de Zootecnia, 39, n. 12, p. 2697-2702, 2010.

NEPOMUCENO, R.C.; WATANABE, P.H.; FREITAS, E.R.; CRUZ, E.B.; PEIXOTO, M.S.M.; SOUSA, M.L. Quality of quail eggs at different times of storage. Ciência Animal Brasileira, 15, n. 4, p. 409-413, 2014.

NURAINI, M.; DJULARDI, A. Effect of turmeric (Curcuma domestica, Val) extract as a feed additive on performance and egg quality of quail. International Journal of Poultry Science, v. 18, n. 2, p. 88-92, 2019.
PARK, S.S.; KIM, J.M.; KIM, E.J.; KIM, H.S.; KI, B.; KANG, C.W. Effects of dietary turmeric powder on laying performance and egg qualities in laying hens. Korean Journal of Poultry Science, 39, n. 1, p. 27-32, 2012.

PRIYADARSINI, K.I. The chemistry of curcumin: from extraction to therapeutic agent. Molecules, 19, p. 20091-20112, 2014. Available at:

http://www.mdpi.com/14203049/19/12/20091/pdf. Access on 13 Apr 2018.

RADWAN, A.L.; HASSAN, R.A.; QUOTA, E.M.; FAYEK, H.M. Effect of natural antioxidant on oxidative stability of eggs and productive and reproductive performance of laying hens. International Journal of Poultry Science, 7, n. 2, p. 134-150, 2008.

RAHARDJA, D.P.; HAKIM, M.R.; LESTARI, V.S. Egg production performance of old laying hens fed dietary turmeric powder. International Journal of Biological, Biomolecular, Agricultural, Food and Biotechnological Engineering, 9, n. 7, p. 748-752, 2015.

RÉHAULT-GODBERT, S.; GUYOT, N.; NYS, Y. The gold egg: nutritional value, bioactivities, and emerging benefits for human health. Nutrients, $v$. 11, n. 3, 684, 2019.

ROCHA, J.S.R.; BARBOSA, V.M.; LARA, L.J.C.; BAIÃO, N.C.; CANÇADO, S.V.; LANA, A.M.Q.; POMPEU, M.A.; VASCONCELOS, R.J.C.; MACHADO, A.L.C.; MIRANDA, D.J.A.; FERNANDES, M.N.S.; MENDES, P.M.M. Efeito do armazenamento e da cantaxantina 
dietética sobre a qualidade do ovo fértil e o desenvolvimento embrionário.

Arquivo Brasileiro de Medicina Veterinária e Zootecnia, 65, n. 3, p. 792-800, 2013.

ROSTAGNO, H.S.; ALBINO, L.F.T.; DONZELE, J.L.; GOMES, P.C.; OLIVEIRA, R.F.; LOPES, D.C.; FERREIRA, A.S.; BARRETO, L.S.T.; EUCLIDES, R.F. Tabelas brasileiras para aves e suínos: composição de alimentos e exigências nutricionais. $3^{\text {rd }}$ ed., Viçosa: Editora Universitária, 2011. 252p.

SANTOS, M.S.V.; ESPÍNDOLA, G.B.; LÔBO, R.N.B.; FREITAS, E.R.; GUERRA, J.L.L.; SANTOS, A.B.E. Efeito da temperature e estocagem em ovos. Ciência e Tecnologia de Alimentos, v. 29, n. 3, 513-517.

SARASWATI, T.R.; MANALY, W.; EKASTUTI, D.R.; KUSUMORINI, N. Increased egg production of Japanese quail (Coturnix japonica) by improving liver function through turmeric powder supplementation. International Journal of Poultry Science, v. 12, n. 10, 601-614, 2013a.
SARASWATI, T.R.; MANALY, W.; EKASTUTI, D.R.; KUSUMORINI, N. The role of turmeric powder in lipid metabolism and its effect on quality of the first quail's egg. Journal of Indonesian Tropical Animal Agriculture, v. 38, n. 2, 123-130, 2013b.

SILVA, W.J.; GOUVEIRA, A.B.V.S.; SOUSA, F.E.; SANTOS, F.R.; MINAFRA-REZENDE, C.S.; SILVA, J.M.S.; MINAFRA, C.S. Turmeric and sorghum for egg-laying quails. Italian Journal of Animal Science, v. 17, n. 2, p. 368-376, 2018.

SUN, J.L.; JI, H.F.; SHEN, L. Impact of cooking on the antioxidant capacity of spice turmeric. Food \& Nutrition Research, v. 63, 3451, 2019.

WANG, Y.; WANG, L.; ZHU, X.; WANG, D.; LI, X. Choleretic activity of turmeric and its active ingredients. Journal of Food Science, v. 81, n. 7, p. H1800-H1806, 2020. 